\title{
An unrelenting flood
}

It is a troubling thought that, in this age of information overload, publishers may be producing too many books about English and sending many of them to ET in the hope of a traditional review. It would be more troubling still, of course, if they didn't send them to us, yet the fact remains that - with so many topics to cover and only 64 pages per issue to do it in - we simply cannot review all these titles as fully as most of them deserve. Lack of time, space, money, and personnel militate against such a service. Indeed, if we did the reviewing as well and as fully as one would like (and as publishers and authors hope), there would be no time or space for the rest of the journal.

Book reviews are a beloved bane for journal editors: review copies arrive unsolicited or by arrangement, and on virtually a daily basis in our case. As they pile up, they are divided into the relevant and the rest. There may or may not be time and opportunity to sound out possible reviewers, and if contacted they may or may not be able or willing to take the work on. If they agree to do so, each book has to be posted off - which is expensive in materials, effort, and money. Such an assigned book may or may not then be reviewed on schedule or at all; if not reviewed, the reasons may or may not be reasonable, and often the book does not come back, or comes back after its immediacy has gone - in which case it probably loses its slot. If a review arrives, it may fit its periodical perfectly or may prove unsuitable - in which case a painful correspondence with the reviewer may follow.

$E T$ has known every kind of pleasure and pain associated with book reviewing, but over the last few years the sheer weight of incoming titles has had its own effect on how things can be done, leading first to shortening conventional reviews (and wherever possible covering several titles in one discussion), then to minireviews set alongside the reproduction of pages from reference books, and finally to compact profiles arranged in themes and usually adopting a non-judgemental approach. This arrangement works well editorially and also from the publishers' perspective: their books at least get in. However, I would be glad of comments on whether it is working well for our readers - confronted as we all are by such an unrelenting flood of titles and so many other calls on our time.

Tom McArthur

The editorial policy of English Today is to provide a focus or forum for all sorts of news and opinion from around the world. The points of view of individual writers are as a consequence their own, and do not reflect the opinion of the editorial board. In addition, wherever feasible, ET generally leaves unchanged the orthography (nomally British or American) and the usage of individual contributors, although the editorial style of the journal itself is that of Cambridge University Press.

(c) Cambridge University Press 1994. No contents may be reproduced by any means without the permission of Cambridge University Press.

English Today (ISSN 0266-0784) is a quarterly. ISBN 0521467217.

Publisher: Cambridge University Press, Edinburgh Building, Shaftesbury Road, Cambridge CB2 2RU. Telephone (0223) 312393

Subscriptions: the current annual subscription price for four issues for libraries and institutions is $₹ 46$ outside North America; $乏 22$ for individuals; $\mathbb{E} 18$ for students and the retired; airmail \&10 per year extra.

Apply to Jane Crossland at the above address.

Advertising Sales: write to the Advertising Promoter at the above address.

USA, CANADA AND MEXICO:

Publisher: Cambridge University Press, 40 West 20th Street, New York, NY 10011-4211. Telephone (212) 9243900.

Subscriptions: the current annual subscription price in USA, Canada and Mexico for libraries and institutions is $\$ 77 ; \$ 36$ for individuals; $\$ 25$ for students and the retired.

Copies are air-freighted to New York to arrive with minimum delay. Apply to Lynda DiCaprio at the above address.

Advertising Sales: write to Elaine Rowland at the above address.

Second class postage paid at New York, NY and at additional mailing offices.

POSTMASTER: send address changes in USA, Canada and Mexico to English Today, Cambridge University Press, 110 Midland Avenue, Port Chester, New York, NY 10573-9864.

Japanese prices for institutions (including ASP delivery) are available from Kinokuniya Company Ltd, P.O. Box 55, Chitose, Tokyo.

Letters to the Editor: write to Dr Tom McArthur, Editor, English Today, 22-23 Ventress Farm Court, Cherry Hinton Road, Cambridge CB1 $4 \mathrm{HD}, \mathrm{UK}$.

A call for papers: in $E T$ 's files we have cuttings/clippings from a wide range of British and North American newspapers, and a scattering of material from many other sources. If readers would care to add to our files by sending in occasional (titled and dated) materials from their local newspapers, etc., this would be a great help in widening the range of usage which we can quote.

Printed in Great Britain at the University Press, Cambridge 